\title{
Hernando de Soto: recipient of the 2017 Global Award for Entrepreneurship Research
}

\author{
Martin Andersson • Daniel Waldenström
}

Accepted: 29 September 2017 / Published online: 6 November 2017

(C) The Author(s) 2017. This article is an open access publication

\begin{abstract}
The 2017 Global Award for Entrepreneurship Research is given to Hernando de Soto, president of the Institute for Liberty and Democracy (ILD) in Lima, Peru. Over the last 30 years, Hernando de Soto has been a world-leading intellectual engaged in academic and public policy discussions on global development. He has made substantial contributions to our understanding of the informal economy and of the importance of property rights to unleash entrepreneurship and alleviate poverty and underdevelopment. His contributions have led to a new and better understanding of the role played by institutions in supporting entrepreneurship, especially in the Third World. Hernando de Soto's work has also had major influences on policy worldwide, both in terms of conceptual understanding and practical policy measures.
\end{abstract}

Keywords Hernando de Soto - Global Award for Entrepreneurship Research · Entrepreneurship · Poverty . Development $\cdot$ Institutions

\footnotetext{
M. Andersson $(\bowtie)$

Department of Industrial Economics, Blekinge Institute of Technology (BTH), Karlskrona, and Research Institute of Industrial Economics (IFN), and Swedish Entrepreneurship Forum, and CIRCLE, Lund University, Lund, Sweden e-mail: martin.andersson@bth.se

D. Waldenström

Research Institute of Industrial Economics and Paris School of Economics, CEPR, IZA, UCFS and UCLS, Paris, France e-mail: daniel.waldenstrom@psemail.eu
}

JEL classification $\mathrm{L} 26 \cdot \mathrm{O} 10 \cdot \mathrm{O} 17 \cdot \mathrm{P} 14$

\section{Introduction}

The 2017 Global Award for Entrepreneurship Research has been awarded to Hernando de Soto, economist and president of the Institute for Liberty and Democracy (ILD) in Lima, Peru. Hernando de Soto's work has shed new light on the role of institutions in entrepreneurship. His analyses of the roots of the informal economy in poor countries have inspired scholars in many different fields and have paved the way for new ways of assessing and measuring the difficulties people face when they try to enter the formal sectors of the economy. de Soto's empirical work is based on the painstaking collection of new and previously unknown data, allowing him to challenge several conventional beliefs regarding poor countries. In particular, he showed that the main problem in many developed countries is not capital but lack of property rights. One of his main arguments is that poorly defined private property rights prevent people in developing countries from making productive use of assets they control but may not formally own.

Hernando de Soto's analyses have led to new approaches to alleviating poverty and underdevelopment by way of reforming property rights systems and business legislation and regulations. His analyses have had-and continue to have - tremendous influence on policy throughout the world, both on the governments of different countries and on international organizations such as the World Bank. For example, his work has been 
a primary source of inspiration for the World Bank's reports on Doing Business around the world. He has also inspired academic scholars to engage in research on previously underexplored areas, including the regulation of entry and the determinants of successful entrepreneurship in emerging markets, as well as the role of private property rights in economic development.

This article provides a broad overview of de Soto's contributions to entrepreneurship research. In this section, we present brief background information about the Global Award for Entrepreneurship Research and a short biography of the award winner for 2017: Hernando de Soto. In section 2, we discuss his main contributions in more detail, section 3 analyzes the impact of his work, and section 4 discusses Hernando de Soto's contribution to entrepreneurship research in general.

1.1 The global award for entrepreneurship research-a brief background

The Global Award for Entrepreneurship Research was initiated in 1996 and has since become the most prestigious prize in entrepreneurship research. It consists of 100,000 Euros and a statuette designed by the internationally renowned Swedish sculptor Carl Milles.

According to the original statutes, the award should be given to "a person who has produced scientific work of outstanding quality and importance, thereby giving a significant contribution to theory-building concerning entrepreneurship and small business development, the role and importance of new firm formation and the role of SMEs in economic development." The main aims of the award are (1) to highlight the importance of research produced in the areas of entrepreneurship and small business, (2) to further stimulate and promote research within these fields, and (3) to diffuse state-of-the-art research among scholars, practitioners, and people involved in small business development.

The domain of entrepreneurship research is broad (Carlsson et al. 2013), which means that entrepreneurship research that can be considered for the award is undertaken in several different disciplines, including economics, management, sociology, history, business administration, geography, and psychology. Any aspect of entrepreneurship research is eligible, including the environment and the organizations in which entrepreneurship is conducted, the character of the entrepreneur (personality, cognitive, and affective aspects), or the role of the entrepreneur and/or the entrepreneurial function in a wider sense (at the level of the community, region, country, or industry). One ambition of the Prize Committee is that the award-winning contributions, seen together over a longer time span, reflect the extraordinary breadth of entrepreneurship as a research field in the social sciences.

The key criteria for prize-worthy contributions are originality and influence (Braunerhjelm and Henrekson 2009). It is recognized that contributions can be influential in many ways. A contribution can, for example, be influential because it has had a significant impact on subsequent scientific work, furthered entrepreneurship as a field (through creating important data bases or by starting influential journals, scientific communities, etc.), furthered entrepreneurship education and training at the academic level, and/or influenced policy making and society more broadly.

When selecting prize-worthy contributions, the Prize Committee emphasizes the qualitative aspects of the contributions of candidates. Quantitative metrics, such as citation counts and impact factor-adjusted publication volumes, do provide important information about candidates, but they will never replace qualitative judgment. This means that quantity will never substitute for quality, and it is even possible for a scholar to receive the award for a single landmark contribution.

\subsection{A short biography of the 2017 award winner:} Hernando de Soto

Hernando de Soto is the 2017 recipient of the Global Award for Entrepreneurship Research. He is President of the Institute for Liberty and Democracy (ILD), which is headquartered in Lima, Peru. He received his education in Switzerland and later worked as an economist, corporate executive, and consultant. He has, for example, served as an economist for the General Agreement on Tariffs and Trade, as President of the Executive Committee of the Copper Exporting Countries Organization (CIPEC), as CEO of Universal Engineering Corporation, as a principal of the Swiss Bank Corporation Consultant Group, and as a governor of Peru's Central Reserve Bank.

He founded ILD in 1981 and, in the early 1990s, he and his ILD team drafted and promoted more than 187 laws designed to give the poorest Peruvians access to economic opportunities, including titles to their property and businesses. He also created the national office of Ombudsman to defend the constitutional and human 
rights of the Peruvian people (Defensoría del Pueblo). Over the last 30 years, de Soto and his colleagues at the ILD have been involved in designing and implementing legal reform programs to empower the poor in Africa, Asia, Latin America, the Middle East, and the former Soviet nations.

In terms of research contributions, Hernando de Soto has published two books about economic and political development: The Other Path (1986) and The Mystery of Capital: Why Capitalism Triumphs in the West and Fails Everywhere Else (2000). The latter has been translated into approximately 30 languages, has sold over 2,000,000 copies worldwide, and has received 25 prizes in Europe and North America. It is the ideas and the data work in these books that form the basis for de Soto's receipt of the Global Award for Entrepreneurship Research.

\section{De Soto's main works: The Other Path and The Mystery of Capital}

De Soto has authored two books that describe the main obstacles to growth in developing economies. The first book, The Other Path, published in 1989, focuses on the role of the informal economy in poor countries and the difficulties that prevent people from entering the formal sectors. In his second book, The Mystery of Capital, published in 2000, he describes how poorly defined private property rights prevent people in developing countries from making use of assets they control but do not formally own.

\subsection{The Other Path}

Originally published in Spanish in 1986, de Soto's international breakthrough book, The Other Path: The Invisible Revolution in the Third World (de Soto 1989), contains a profound critique of the workings of the Peruvian economy. This book illustrates the difficulties that poor entrepreneurs face when trying to build housing, provide transportation, and sell goods, primarily in the cities. These difficulties stem from the innumerable bureaucratic obstacles in the Peruvian economy that make it almost impossible to carry out worthwhile projects legally. Because of this, efforts are diverted into illegal and extra-legal activities, all of which generate substantial social costs and inefficiencies.
Among the most important contributions of the book is its anecdotal evidence of the time and energy required to work one's way through legal hurdles to enter the formal economy. In particular, de Soto presents a detailed account of the obstacles a Peruvian entrepreneur faces when trying to establish a small garment factory. De Soto himself attempts to secure a building permit, establish legal title to a piece of land, and obtain a license for a taxi route. At each step, de Soto shows how tiresome, troublesome, and time consuming it is to follow all the requirements of the law.

The conclusion is that bad laws - and not bad people - are the cause of the extensive number of "illegal" entrepreneurial activities in Third World countries such as Peru. In de Soto's own words, "in order to survive, the migrants became informals. If they were to live, trade, manufacture, transport or even consume, the cities' new inhabitants had to do so illegally." De Soto argues that politics, rather than markets, govern Peru's economy, and they do so inefficiently. In contrast to a developed market economy, where anyone can enter the market, the barriers to entry in Peru are huge, with people "having to waste 289 days on red tape before being able to operate an industry, or having to wait almost seven years before being able to build a house."

\subsection{The Mystery of Capital}

De Soto's second book, The Mystery of Capital: Why Capitalism Triumphs in the West and Fails Everywhere Else (de Soto 2000), builds on his first book and is arguably his most important contribution to date. In this book, de Soto focuses on what he sees as the main obstacle to growth in developing economies: poorly defined private property rights. In contrast to the general conception that there is a lack of capital in poor countries and that it is this lack that prevents these countries from developing, de Soto argues that there are vast amounts of capital in these countries. The problem is that this capital is not readily available for economic use. More specifically, all around the Third World, there are large numbers of settlers and squatters inhabiting rural and urban dwellings without owning them. This lack of formal titles prevents these people from making productive use of "their" property, e.g., as collateral for a bank loan. De Soto calls this capital "dead" and calls for property reform to revive it.

This book contains similar investigations as The Other Path. In fact, de Soto draws on the findings of his first 
book, especially those showing that bureaucracy and stiff laws in Peru are what prevent people from entering the formal economy. The Mystery of Capital can thus be interpreted as a quest to identify the underlying sources of these legal obstacles and how they can be removed. With the help of his research team and local associates in other countries, de Soto expanded his inquiry to include studies of conditions in Egypt, Haiti, Mexico, and the Philippines. His general finding is that the "obstacles were no less formidable than in Peru, often they were oven more daunting." In fact, in every country de Soto's group investigated, they found that "it is very nearly as difficult to stay legal as it is to become legal."

The group also estimated the value of "dead" capital by collecting data on the share of informal settlements in the capitals of the four countries, including data on these settlements' market value. From this, they extrapolate these numbers to the entire Third World and arrive at a total valuation of the poor's "dead" capital: 9.34 billion US dollars, equivalent to the entire value of the world's largest stock exchange (NYSE). While this exact figure has been debated (Woodruff 2001), it illustrates the importance of dead capital throughout the Third World.

De Soto also delves into history to make his case about the benefits of specifying private property rights through, in particular, land titling. This is mainly done through a retelling of the economic history of the Western world, in which such institutional reforms have been carried out since the seventeenth century with great success. For example, de Soto mentions the English enclosure movement and the exploration of the North American West in the nineteenth century.

The book's main policy conclusion is that governments should offer formalized ownership to squatters and settlers. Given the large amount of underutilized and "dead" capital in poor countries, de Soto argues that providing urban and rural squatters with formalized ownership offers a tangible way out of poverty and underdevelopment. As de Soto himself states, "The poor are not the problem; they are the solution."

\section{Impact of de Soto's work}

\subsection{Impact on policy}

Hernando de Soto is, without a doubt, a central figure in the conversation about global development, and he has put issues related to entrepreneurship and institutions in the Third World at center stage. His two best-selling books and their main ideas have been embraced by world leaders from both developed and developing countries, including former presidents Vladimir Putin in Russia and Vicente Fox in Mexico, as well as UN Secretary-General Ban Ki-Moon. The cover of The Other Path contains endorsements by no less than four former U.S. presidents (Richard Nixon, Ronald Reagan, George Bush, and Bill Clinton). The Economist hailed The Mystery of Capital as being "the most intelligent book yet written about the current challenge of establishing capitalism in the developing world" (Clift 2003).

Since then, de Soto has been continuously recruited to guide international policy work. For example, de Soto co-chaired a recent UNDP project together with former U.S. Secretary of State Madeleine Albright. The project, called the Commission on Legal Empowerment for the Poor, released its final report last year (Albright and de Soto 2008), and its conclusions presented four pillars on which future policy actions in the developing world should rest: (1) access to justice and the rule of law, (2) property rights, (3) labor rights, and (4) business rights. The impact of the commission is still uncertain.

Another policy area in which de Soto's ideas have had a tremendous influence concerns the work of international organizations, especially the World Bank. Ever since the publication of The Other Path, and even more significantly after The Mystery of Capital, the World Bank has incorporated the ideas of de Soto, particularly by focusing on improved private property rights and simplified legal frameworks for incorporation. Several projects are also explicitly framed around de Soto's work.

Consider the following two examples from the World Bank. The foreword of a cross-country project on the institutions promoting businesses ventures states: "The report builds on noted economist Hernando de Soto's work, showing that while it is critical to encourage registration of assets, it is as important - and harder - to stop them from slipping back into the informal sector." (World Bank 2005a). Another World Bank project on entry regulation, headed by Simeon Djankov, among others, states that "this work owes a great deal to de Soto's path-breaking study of entry regulation" (cited in Woodruff 2001).

\subsection{Impact on research}

Although Hernando de Soto may be an atypical award winner in the sense that he is not an academic scholar with a significant publication record of academic 
articles, his work has received significant and broad attention from the academic community, particularly in the areas of institutional economics, development economics, and entrepreneurship research. To illustrate, the numbers of citations of de Soto's two books in one of the world's largest citation databases, Google Scholar, are significant. The Other Path has received over 2,000 citations and The Mystery of Capital over 7,000.

Furthermore, some of the world's most renowned academic scholars have also become admirers of de Soto's work, especially his theses in The Mystery of Capital. Nobel laureate Ronald Coase has called it "a very great book... powerful and completely convincing. It will have the most salutary effect on the views of economic development." Another Nobel laureate, Milton Friedman, states that "De Soto has demonstrated in practice that titling hitherto untitled assets is an extremely effective way to promote economic development of society as a whole. He offers politicians a project which can contribute to the welfare of their country and at the same time enhance their political standing, a wonderful combination." Jagdish Bhagwati, one of the world's most prominent development economists, has stated that "de Soto is arguably the most interesting intellectual writing on development today... [He] is the man with 'big' ideas. ... His Mystery of Capital will endure as a work of extraordinary importance (all quotes from Ahiakpor 2008). Altogether, these endorsements and citation counts show that the contributions of Hernando de Soto have had a decisive influence on the academic community.

\subsection{De Soto's impact on development outcomes}

To fully describe the impact of de Soto's work is practically impossible, given its widespread impact as well as the difficulties of assessing the true effects of de Soto's proposed reforms. Nevertheless, this section lists a few examples of positive outcomes that have resulted from following de Soto-inspired policies.

It is, of course, highly interesting to see whether improved property rights reforms, such as land titling, have notable economic effects in poor countries. In a study of the productive effects of possessing land titles in Ghana, Besley (1995) finds that farmers with formal ownership make significantly higher investments in improved crops and other farm products than farmers without such titles. Besley argues that this difference is primarily incentive-driven, which is consistent with the private property rights approach. Similarly, Lanjouw and Levy (2002) found that property owners in Ecuador invested more in their lands following a reform that strengthened their property rights.

There is also plenty of international evidence showing that improved specification of property rights (mainly through titling reforms) leads to increased values of dwellings in both urban and rural settlements. An overview is provided in the World Development Report of 2005 (World Bank 2005b, ch. 4). The report describes agricultural reforms in Brasilia, Indonesia, the Philippines, and Thailand and how land values increased by between 43 and $81 \%$ after ownership was formalized. Similarly, post-reform values of urban housing increased by between 14 and $58 \%$ in the cities of Manila and Davao in the Philippines, Guayaquil in Ecuador, and Lima in Peru.

Alston et al. (1996, 1999) analyze the commercial expansion in the Amazon jungles, where large areas of previously uncultivated soil were given to large-scale farmers but also to large groups of landless people. The results of these privatization reforms have not been entirely positive. Still, the authors found that possessing titled land increased the land value by between 20 and $50 \%$. Furthermore, the reform seems to have spurred efficiency gains in production, although these are difficult to establish statistically because many other institutional changes accompanied the land reform. More importantly for the net benefits, the reforms were preceded by extensive conflicts (and costs associated with them) between interest groups striving for the largest possible portions of the redistributed land.

Overall, the above examples clearly show that de Soto's ideas and policy reforms may have significantly positive effects on economic development in Third World countries. One should, of course, be cautious with interpreting the observed relationships as strictly causal, but the before-and-after reform analyses are still indicative.

\subsection{Critical assessments of de Soto's policy proposals}

Notwithstanding the importance of de Soto's work for academic research and development policy, his explicit policy proposals have also been met by numerous critical responses.

One example of this criticism concerns the methodological approaches used in de Soto's investigations in The Other Path and The Mystery of Capital. Academic 
scholars attempting to replicate the results in these books have faced considerable difficulties. For example, Rossini and Thomas (1990) found inconsistencies and problems in the methods used in the calculation of the number of workers and hours worked in the informal sector in Peru. Woodruff (2001) replicated the estimate of the "dead capital" owned by the Third World's poor, but found it to be only about one third of de Soto's original estimate. Woodruff explains this difference by the fact that de Soto extrapolates data from only four countries (Egypt, Haiti, Peru, and the Philippines) to the entire developing world, as well as by the fact that the shares and values of informal settlements that de Soto presents for urban areas are not always plausible.

From a policy perspective, perhaps the most important line of critique against de Soto's property rights program concerns the practical problems associated with it. Critics argue that de Soto grossly exaggerates the benefits of land reforms, as he ignores all of the costs they may generate. Several researchers have documented that the costs of land titling may be large, especially for very poor households. In a study of informal urban dwellings in Ecuador, Lanjouw and Levy (2002) estimate the costs to be more than $100 \%$ of the value of an average low-income household's total annual consumption. (However, this concerns one-time costs, which may diminish in importance if one takes a long-run perspective). Gilbert (2002) also notes that formalized ownership brings with it other unexpected additional expenses, in particular property taxes.

The role of credit markets is relatively unimportant in de Soto's work. Land titles do not automatically boost people's welfare. For this to happen, credit markets need to work effectively with land titles, which are used as collateral for bank loans. However, available research suggests that poor people are not keen to borrow from banks at all, with or without a legal title to their house or piece of land. In general, banks are primarily interested in customers with sufficient incomes to pay interest, and because the poor have low and variable incomes, they are less likely to receive loans regardless of collateral. Surveys in developing countries (Gilbert 2002) indicate that poor people refrain from taking loans even when they have titles because they fear losing their land in the event of a credit default. Among the poor who actually do take bank loans, moreover, land titles seem to play a minor role as collateral, as Johnston and Morduch (2008) have found in a study of microfinancing in six Indonesian provinces. In addition, credit market imperfections may also skew the gains from land titling towards large farmers and away from smaller farms. Carter and Olinto (2003) study rural Paraguay and find that it was primarily relatively large farmers who reaped the gains of the formalization of property rights through the formal banking sector. Most small farmers were unable to obtain good loans from the banks, even with a land title.

In response to criticism along these lines, Hernando de Soto has argued that property law is not a silver bullet but rather an important missing link and that other reforms will not work unless the issue of extralegality is addressed (Clift 2003).

\section{Hernando de Soto's work and entrepreneurship research}

The key contribution of Hernando de Soto's work to entrepreneurship research lies in his original and highly influential analyses of the role that institutions play in entrepreneurship. First, his work has clarified the role that institutions play in allocating entrepreneurial efforts in society, specifically between informal and formal activities in poor countries. For example, in The Other Path, de Soto argues forcefully that "a country's entrepreneurial reserves do not automatically function properly, they do so only if prevailing institutions allow them to" (p. 244). Second, de Soto's arguments and empirical accounts of the role that the property rights system plays in the ability to put assets to productive use are original and provide novel evidence that well-defined property rights are a fundamental determinant of productive entrepreneurship. In The Mystery of Capital, de Soto argues that a main problem in many Third World countries is the lack of processes for documentation and representation of property rights, as well as lack of protection for these rights. This implies that a significant fraction of residents hold assets in defective form: "Because the rights to these possessions are not adequately documented, these assets cannot readily be turned into capital, cannot be traded outside of narrow local circles where people know and trust each other, cannot be used as collateral for a loan and cannot be used as a share against investments" (p. 6). This institutional deficiency suppresses productive entrepreneurship. Without documented property rights, assets cannot be turned into capital, i.e., the capital is "dead." Third, de Soto pioneered detailed empirical analyses of the hurdles that 
prospective entrepreneurs face when they try to open a business and become part of the formal economy. His and his team's data collection efforts and novel method of empirically assessing the consequences, for prospective entrepreneurs, of ill-functioning institutions and regulatory burdens are truly original. They have paved the way for new types of empirical analyses, for example of how business legislation and regulatory burdens impact entrepreneurial efforts in countries and regions all over the world.

Hernando de Soto's work connects with the work of scholars such as Baumol (1990), North (1990), and Rosenberg and Birdzell (1986), in terms of both time of publication and in the broad nature of the arguments. North (1990) argued that institutions are the fundamental cause of growth and that it is the incentive structures in society that encourage individual effort and investment in physical and human capital and new technology. In his famous article on productive and unproductive entrepreneurship, in fact published 1 year after de Soto's book The Other Path was published in English, Baumol (1990) made the case that it is the social structure of payoffs that channels entrepreneurship to different activities - some productive, some unproductive. The historical analysis of the transformation of western economies by Rosenberg and Birdzell (1986) emphasized the critical role of property rights and their protection in fueling investments, entrepreneurship, and growth. By now, it is widely acknowledged that institutions are critical in allocating entrepreneurial efforts in society (Henrekson 2007) and that institutions, in particular protection of property rights, are fundamental determinants of growth (Rodrik et al. 2004, Acemoglu and Johnson 2005). By emphasizing the link between entrepreneurship and economic development, de Soto's work also connects to more recent research on the role that national systems of entrepreneurship play in economic development (Acs et al. 2017).

What makes de Soto's work unique and original are its emphasis on the developing world and its consistent focus on identifying how and in what ways the realworld problems faced by prospective entrepreneurs are linked to a country's institutional set-up. This emphasis includes conceptual framing as well as painstaking gathering of new types of detailed data.

De Soto's work does not analyze the impact of institutions from the viewpoint of a heroic Schumpeterian entrepreneur who distorts markets and brings new hightech products and innovations to a modern market; nor does his research resort to general remarks about the role of institutions. Hernando de Soto's contribution to entrepreneurship research is that he has clarified and empirically analyzed (a) the real-world problems that ordinary people in poor countries face when trying to enter the formal economy as entrepreneurs and when trying to turn their assets into capital, and (b) how these problems are linked to specific properties of the institutional setup in poor countries. This has enriched our understanding of (i) what the essential components of an institutional set-up are and (ii) the mechanisms by which these institutional components influence the allocation and direction of entrepreneurial efforts. His insights have led to new ways of thinking about the role of institutions and entrepreneurship in alleviating informality and poverty in the developing world and have suggested novel policy tools for development work.

\section{Concluding remarks}

The work of Hernando de Soto has had a tremendous impact on both policy makers and academics worldwide. His two books have received a large number of academic citations, placing them well on par with the world's most prominent scholars dealing with similar issues.

De Soto's thoughts on the role of institutions and entrepreneurship in development have been adopted repeatedly by governments and international organizations. de Soto has also inspired academic scholars to do research on previously underexplored areas, particularly on questions concerning the regulation of entry and the determinants of successful entrepreneurship in emerging markets, as well as the role of private property rights in economic development. Hernando de Soto is a worthy recipient of the 2017 Global Award for Entrepreneurship Research.

Open Access This article is distributed under the terms of the Creative Commons Attribution 4.0 International License (http:// creativecommons.org/licenses/by/4.0/), which permits unrestricted use, distribution, and reproduction in any medium, provided you give appropriate credit to the original author(s) and the source, provide a link to the Creative Commons license, and indicate if changes were made.

\section{References}

Acemoglu, D., \& Johnson, S. (2005). Unbundling institutions. Journal of Political Economy, 113(5), 949-995. 
Acs, Z., Lafuente, E., Sanders, M., \& Szerb, L. (2017). The global technology frontier: productivity growth and the relevance of the national system of entrepreneurship, Working Paper.

Ahiakpor, J. C. W. (2008). Mystifying the concept of capital: Hernando de Soto's misdiagnosis of the hindrance to economic development in the Third World. Independent Review, 13(1), 57-79.

Albright, M. K., \& de Soto, H. (2008). Making the Law work for everyone. Volume I: Report of the Commission on Legal Empowerment for the Poor, Washington, UNDP, Downloadable at: http://www.undp.org/legalempowerment/ (2005-03-05)

Alston, L. J., Libecap, G. D., \& Schneider, R. (1996). The determinants and impacts of property rights: land titles on the Brazilian frontier. Journal of Law, Economics, and Organization, 12(1), 25-61.

Alston, L. J., Libecap, G. D., \& Mueller, B. (1999). Titles, conflict and land use: the development of property rights and land reform on the Brazilian frontier. Ann Arbor: University of Michigan Press.

Baumol, W. J. (1990). Entrepreneurship: productive, unproductive and destructive. Journal of Political Economy, 98(5), 893921.

Besley, T. (1995). Property rights and investment incentives: theory and evidence from Ghana. Journal of Political Economy, 103, 903-937.

Braunerhjelm, P., \& Henrekson, M. (2009). Awarding entrepreneurship research: a presentation of the global award. Entrepreneurship Theory and Practice, 33(3), 809-814.

Carlsson, B., Braunerhjelm, P., McKelvey, M., Olofsson, C., Persson, L., \& Ylinenpää, H. (2013). The evolving domain of entrepreneurship research. Small Business Economics, 41(4), 913-930.

Carter, M. R., \& Olinto, P. (2003). Getting institutions "right" for whom? Credit constraints and the impact of property rights on the quantity and composition of investment. American Journal of Agricultural Economics, 85(1), 173-186.
Clift, J. (2003). Hearing the dogs bark. Finance \& Development, Dec., 8-11.

de Soto, H. (1989). The other path: the invisible revolution in the Third World. New York: Harpercollins.

de Soto, H. (2000). The mystery of capital: why capitalism triumphs in the West and fails everywhere else. New York: Basic Books.

Gilbert, A. (2002). On the mystery of capital and the myths of Hernando de Soto. International Development Planning Reivew, 24(1), 1-19.

Henrekson, M. (2007). Entrepreneurship and institutions. Comparative Labor Law \& Policy Journal, 28(4), 717-742.

Johnston Jr., D., \& Morduch, J. (2008). The unbanked: evidence from Indonesia. World Bank Economic Review, 22(3), 517537.

Lanjouw, J. O., \& Levy, P. I. (2002). Untitled: a study of formal and informal property rights in urban Equador. Economic Journal, 112, 986-1019.

North, D. C. (1990). Institutions, institutional change and economic performance. Cambridge: Cambridge university press.

Rodrik, D., Subramanian, A., \& Trebbi, F. (2004). Institutions rule: the primacy of institutions over geography and integration in economic development. Journal of Economic Growth, 9(2), 131-165.

Rosenberg, N., \& Birdzell, L. E. (1986). How the West grew rich: the economic transformation of the western world. New York: Basic Books.

Rossini, R. G., \& Thomas, J. J. (1990). The size of the informal sector in Peru: a critical comment on Hernando de Soto's El Otro Sendero. World Development, 18(1), 1-19.

Woodruff, C. (2001). Review of de Soto's The Mystery of Capital. Journal of Economic Literature, 39(4), 1215-1223.

World Bank (2005a). Doing business 2005: poor nations struggle to reduce red tape for business, miss large growth opportunities. Washington, DC: World Bank.

World Bank (2005b). World development report 2005: A better investment climate for everyone. Washington, DC: World Bank. 